\title{
Synthesis of Chitosan from the Scales of Starry Trigger Fish (Abalistes stelaris)
}

\author{
INDRI HERMIYATI ${ }^{1}$, ISWAHYUNI ${ }^{1}$ and SWATIKA JUHANA ${ }^{2 *}$ \\ 'Department of Rubber and Plastic Processing Technology, Politeknik ATK Yogyakarta, Indonesia. \\ ${ }^{2}$ Department of Leather Processing Technology, Politeknik ATK Yogyakarta, Indonesia. \\ ${ }^{*}$ Corresponding author E-mail: swatika.rustiawan@gmail.com
}

http://dx.doi.org/10.13005/ojc/350147

(Received: November 01, 2018; Accepted: November 28, 2018)

\begin{abstract}
Synthesis of chitosan from the scales of starry trigger fish has been carried out in three stages: deproteination using $10 \% \mathrm{NaOH}$ solution, demineralization using $0.63 \mathrm{M} \mathrm{HCl}$ solution, and deacetylation using $\mathrm{NaOH}$ solution with three different concentration of $\mathrm{NaOH}$, those were $60 \%, 50 \%$, and $40 \% \mathrm{NaOH}$. Characterization of synthesized chitosan showed that the best chitosan was obtained by deacetylation process with $60 \% \mathrm{NaOH}$. The degree of deacetylation obtained $74 \%$ has met the DD standard of at least $70 \%$ chitosan. Ash level $88.05 \%$; $6 \%$ water content; $2.29 \%$ protein content.
\end{abstract}

Keywords: Chitosan, Starry Trigger fish, Deacetylation degree.

\section{INTRODUCTION}

The use of biopolymers has developed in all aspect, one of biopolymer is chitosan which is use as biopreservative, emulsificator, stabilizator ${ }^{1}$. Chitosan can be derived from Chitin which is synthezed from solid waste of crustaceans such as shells, heads, feet and scales, and from scales of some fishes ${ }^{2}$. By using the waste product as cheap and readily found in natural resources hopefully would solve the problems of solid waste in the seafood processing industry. One of fish that can be use as natural natural source is the scales of starry trigger fish (Abalistes stelaris).

The increasing consumption of starry trigger fish is followed by the increase solid wastes such as skin, bone and scales of the fish. The physical properties of starry trigger fish are very hard outer skin and the scales cannot be cleaned with scales cleaning tool. Due to those uninteresting physical properties, the consumers only consume the flesh; while the skins as well as the scales are discarded around the beach thus became solid wastes. The amount of starry trigger fish skin that were discarded in around Tasik Agung beach, Rembang district, Central Java, Indonesia reached about 25 to $50 \mathrm{~kg}$ per day or $50-1500 \mathrm{~kg}$ per month. This waste product of fish skin has been utilized to produce valuable leather products by tanning using vegetable tanning process ${ }^{3}$. Now, the skin of this fish has been tried to synthesize chitosan and characterize by FTIR to determine the formation of $\mathrm{NH}_{2}$ groups in chitosan and to calculate the deacetylation degree of chitosan.

This is an Open Access article licensed under a Creative Commons license: Attribution 4.0 International (CC- BY). Published by Oriental Scientific Publishing Company @ 2018

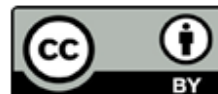


The use of the scales of starry trigger fish to produce chitosan will increase valuable products and helps to overcome solid wastes around the beach.

Chitosan can be syntheses from chitin which is extracted from some scales fish. ${ }^{2}$ Chitin was first discovered in 1811 by Henry Braconot by extracting certain types of fungi using water, alcohol and dilutes alkalis that produce insoluble deposits called fungi. The extraction results as a pure form of cellulose although the presence of nitrogen is unknown. Then in 1823 Odie found the same component in the insect ectodermal (cuticle) and named it chitin from the Greek word "chiton" which means cover or cover.

Chitin is composed of units of acetyl glucosamine which bind to each other, with (1-4) beta bonds. Chemically chitin is a polysaccharide group polymer composed of units of $\beta$ - (1-4) 2-acetamide2-deoxy-D-glucose, which can be digested by mammals. Chitin is a formless solid (amorphous), insoluble in water, dilutes organic acids, dilute and concentrated alkalis, alcohol, has a physical form in the form of crystals which are white to light yellow, tasteless, and odorless with the molecular formula $\left.\left[\mathrm{C}_{6} \mathrm{H}_{13} \mathrm{O}_{5} \mathrm{~N}\right]\right\urcorner \mathrm{n}$. The molecular weight of chitin is very large depending on the length of the chain. From the molecular formula above, the molecular weight is $[203,19]_{n}$. Chitin has no melting point, and has a nitrogen content of less than $7 \%$. Chitin is obtained from scales waste through deproteinization and demineralization processes. Deprotenation is the process of removing protein, which is extracted with $\mathrm{NaOH}$ solution. In principle the deproteinization process is to separate or release bonds between protein and chitin. This process is generally carried out with treatment using $\mathrm{NaOH}$ solution at relatively high temperatures for a relatively long time. With this treatment protein will be released and form soluble Na-proteinate. Demineralization is a stage in the removal of minerals which serves to separate chitin from inorganic salts by adding dilute $\mathrm{HCl}$ at room temperature, so that the existing minerals will react with $\mathrm{HCl}^{4}{ }^{4}$ The reactions that occur are as follow:

$\mathrm{CaCO}_{3(\mathrm{~s})}+2 \mathrm{HCl}_{(\mathrm{s})} \mathrm{CaCl}_{2}(\mathrm{l}) \longrightarrow+\mathrm{H}_{2} \mathrm{O}_{(\mathrm{g})}+\mathrm{CO}_{2}(\mathrm{~g})$ $\mathrm{Ca}_{3}\left(\mathrm{PO}_{4}\right)_{2(\mathrm{~s})}+6 \mathrm{HCl}_{(\mathrm{l})} \longrightarrow 3 \mathrm{CaCl}_{2(\mathrm{l})}+2 \mathrm{H}_{3} \mathrm{PO}_{4}$

Treatment with dilute hydrochloric acid at room temperature is more effective and produces chitin with a lower residual mineral content, although it can cause breaking of the chain or the release of its acetyl groups. Chitosan is chitin which is removed by acetyl group, so this material is a polymer of glucosamine which is also called $\beta-1,4-2$, amino2-dioxy-D-glucose. (Muzarelli, 1985 in Suhardi, 1992). 5 Chitosan is white, non-toxic, odorless, easily biodegradable, and slightly soluble in $\mathrm{HCl}, \mathrm{HNO}_{3}$ and $\mathrm{H}_{3} \mathrm{PO}_{4}$. The free amino groups they contain make this polymer polycationic so it is not soluble in water and dissolves in strong bases. Chitosan is also insoluble in organic solvents such as alcohol, acetone, dimethylformamide, dimethylsulfoxide, but is easily soluble in organic acids such as citric acid and high concentrated formic acid $(0.2 \%-100 \%)$ in water. ${ }^{6}$ Besides that chitosan easily interacts with organic substances such as proteins, so it is relatively more widely used in various applied industries and the health industry.

Chitosan has the same chemical structure as chitin, consisting of long molecular chains and large molecular weight. The difference between chitin and chitosan is that in each ring of chitin molecules there is an acetyl group ( $\left.\mathrm{CH}_{3}-\mathrm{CO}-\right)$ on the second carbon atom, whereas in chitosan there is an amine group $\left(\mathrm{NH}_{2}-\right)$. Chitosan contains more than $7 \%$ nitrogen (Figure 1). ${ }^{7}$

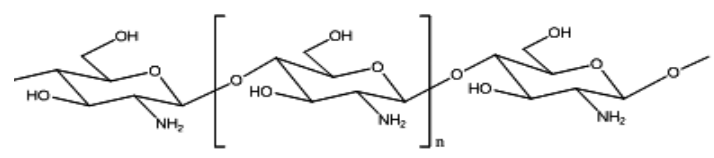

Fig. 1. The structure of chitosan

Chitosan can be produced from chitin by deacetylation process by reacting using high concentration alkali with relatively long time and high temperature, by removing acetyl group $\left(-\mathrm{COCH}_{3}\right)$ so that the molecule can dissolve in acid solution. This process is called deacetylation, which releases acetyl groups so that chitosan has the characteristics of a cation. In general, the deacetylation degree of chitosan is around $60 \%$ and around $90-100 \%$ for chitosan which has full deacetylation, this price depends on the chitin raw material used and the process carried out. ${ }^{4}$

The degree of deacetylation was influenced by alkaline solution concentration, temperature, reaction time, chitin pre-treatment, particle size and chitin concentration. ${ }^{8}$ 
One of the quality parameters of chitosan is the degree of deacetylation. The degree of deacetylation is a parameter of chitosan quality which shows the percentage of acetyl groups that can be removed from chitin yield. The higher the deacetylation degree of chitosan, the lower the acetyl chitosan group so that the interaction between ions and hydrogen bonds becomes stronger. The more amine groups in chitosan also cause chitosan to become more reactive. The quality parameters of chitosan according to ${ }^{9}$ are shown in Table 1.

Table 1: The quality parameters of chitosan

\begin{tabular}{lc}
\hline Quality Parameters & Standard value of chitosan \\
\hline Particle size & Pellets \\
Ash content $(\% \mathrm{~b} / \mathrm{b})$ & $<1.0$ \\
Moisture content $(\% \mathrm{~b} / \mathrm{b})$ & $<10.0$ \\
Solubility in an acidic atmosphere & $>95.0$ for pharmacy types \\
Color & Only at $\mathrm{pH}<6$ \\
Deacetylation degree $(\%)$ & $>70.0$ for technical types \\
\hline
\end{tabular}

\section{MATERIALS AND METHODS}

\section{Research Materials}

The scales of starry trigger fish as waste product were collected from the fishermen in Tasik Agung beach, Rembang district, Central Java Province, Indonesia. The reagent and chemicals used in this study were such as sodium hydroxide hydrochloric acid, and $\mathrm{pH}$ indicator paper. The chemicals were purchased from Merck \& Co.

\section{Pretreatment of raw material}

The scales of starry trigger fish were cleaned by washing in running water, then they were dried under the sun. The dried fish scales were mashed to a size of 100 mesh.

\section{Isolation of Chitin}

Prior to chitin isolation the scales of starry trigger fish were cleaned by washing in running water, and then they were dried under the sun. The dried fish scales were mashed to a size of 100 mesh. Chitin isolation was carried out through deproteinization stage by refluxing $50 \mathrm{~g}$ of the scales powder with $500 \mathrm{ml}$ of $4 \%(\mathrm{w} / \mathrm{v}) \mathrm{NaOH}$ solution at $65^{\circ} \mathrm{C}$ for $2 \mathrm{~h}$ then it was refluxed with distilled water until the $\mathrm{pH}$ reached neutral and the resulting filtered was dried in the oven. After the deproteination the process was continued with the demineralization process, the residue plus $0.5 \mathrm{M} \mathrm{HCl}$ with a ratio of
1:15 was stirred at room temperature for 3 hours. The aim of demineralization was to remove minerals $\left(\text { mainly } \mathrm{CaCO}_{3}\right)^{10}$. Then the mixture was filtered and washed with distilled water until the $\mathrm{pH}$ was neutral. The washing residue was heated in the oven, and it was called chitin.

\section{Synthesis of Chitosan}

Synthesis of chitosan was carried out through a deacetylation process. $50 \mathrm{~g}$ of chitin were refluxed with three different concentration of $\mathrm{NaOH}$ with a ratio of $1: 10$ at $70^{\circ} \mathrm{C}$ for 1 hour. Concentration of $\mathrm{NaOH}$ for deacetylation is chitosan 1 with $60 \%$ $\mathrm{NaOH}$, chitosan 2 with $50 \% \mathrm{NaOH}$, chitosan 3 with $40 \% \mathrm{NaOH}$. The reflux product was cooled and filtered to a neutral washing $\mathrm{pH}$. The residue was then heated using an oven and the chitosan was obtained. The chitosan obtained will be in a creamy white form. ${ }^{11}$

\section{Characterization of chitin and chitosan}

The characterization of chitin and chitosan was carried out by using the described method $^{12}$ including moisture content, ash content, protein content and deacetylation degree.

\section{Moisture Content}

One gram of chitosan was put in a porcelain cup then it was heated in the oven at $105^{\circ} \mathrm{C}$ for $3 \mathrm{~h}$ then it was cooled in a desiccator and weighed. The water content of chitosan was calculated by calculating the moisture content (\%) was calculated by using this formula: (weight of chitin or initial chitosan (gram) -weight of chitin or final chitosan gram per weight of chitin or initial chitosan (gram) $\times 100$.

\section{Ash content}

One gram of dried chitin or chitosan was put into a cup, then burned on an electric stove until no longer smoky and then put in the furnace for $5 \mathrm{~h}$ at $650^{\circ} \mathrm{C}$. The cup was cooled in a desiccator then weighed. Ash content was calculated as follows: (Weight of ash/weight of sample) x 100 .

\section{Protein content}

Protein content analysis consists of three stages: destruction, distillation and titration. A total of $0.25 \mathrm{~g}$ of chitin or chitosan were added to 100 $\mathrm{mL}$ of Kjeldahl flask and added with one Kjeltab 
and $3 \mathrm{~mL}$ of concentrated $\mathrm{H}_{2} \mathrm{SO}_{4}$. The mixture was destructed at $410^{\circ} \mathrm{C}$ for $1 \mathrm{~h}$ until the solution was clear and cooled down. The mixture in Kjeldahl flask was added with $50 \mathrm{~mL}$ of distilled water and $20 \mathrm{~mL}$ of $40 \% \mathrm{NaOH}$ and distilled at $100^{\circ} \mathrm{C}$. The distilled water in an Erlenmeyer flask was added with a mixture of $2 \mathrm{~mL}$ of $2 \%$ boric acid and 2 drops of bromocresol green-methyl red indicator. The distillation process was stopped when the volume of distillate reached $40 \mathrm{~mL}$ and the color was bluish green. The distillate was then titrated with $0.1 \mathrm{~N} \mathrm{HCl}$ until a pink color was formed. Protein levels were determined by calculating nitrogen content (\%) using this formula: $((\mathrm{mL} \mathrm{HCl}-\mathrm{mL}$ blank) x N HCl x 14,007/ mg sample) x 100\%.

\section{The degree of deacetylation (DD)}

FTIR spectrum chitosan synthesized from starry trigger fish scales were recorded using FTIR spectrophotometer (FT-IR 8400S, Shimadzu, Japan). The degree of deacetylation (DD) was determined by infrared spectrophotometry methods. The deacetylation degree of chitin and chitosan can be calculated based on the comparison of the absorbance of amide groups (about $1655 \mathrm{~cm}^{-1}$ ) with hydroxyl groups (about $3450 \mathrm{~cm}^{-1}$ ). The absorbance ratio was calculated after firstly determined the baseline in each spectra so as to produce two different baselines in the absorption area of 1655 $\mathrm{cm}^{-1}$ namely baseline $A$ and $B .^{13}$

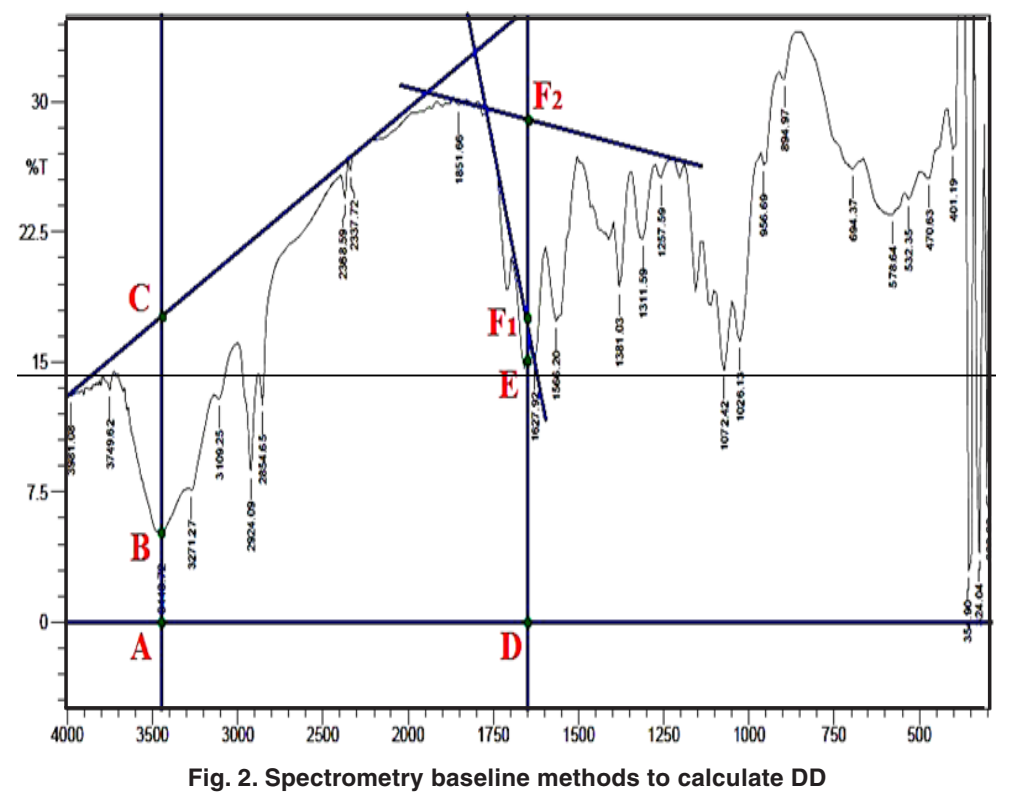

Figure chitosan 2 shows the chitosan FTIR spectra from the deacetylation process with $50 \%$ $\mathrm{NaOH}$. The spectra results show there was an $-\mathrm{OH}$ group of chitosan groups which were shown in wave numbers $1412.87 \mathrm{~cm}^{-1}$ with low intensity, $-\mathrm{CH}$ groups at wave numbers $1469 \mathrm{~cm}^{-1},-\mathrm{CO}$ groups at wave numbers $1025.75 \mathrm{~cm}^{-1}, \mathrm{CH}$-alkene groups at wave number 872.70 . The calculation of deacetylation degree for this chitosan wass $47.58 \%$. The formula for determining baseline A based on the Domzy and Robert formula ${ }^{14}$ is as follows:

$\mathrm{DD}=100-\left[\left(\left(\frac{\mathrm{A}_{1655}}{\mathrm{~A}_{3450}}\right) / 1,33\right) \times 100\right]$

The area of absorbance of amine groups and hydroxyl groups can be presented further by the mathematical equations proposed by Sabnis and Block as bellow:

$$
\begin{aligned}
& \log \left(D_{1} / D E\right)=A_{1655} \\
& \log \left(D_{2} / D E\right)=A_{1655} \\
& \log (A C / A B)=A_{3450}
\end{aligned}
$$

DF1 (used for baseline A) or DF2 (used for baseline $B$ ), DE, AC and B show the absorbance band of the functional group as the wavelength region.

\section{RESULTS AND DISCUSSION}

The results of chitosan rendement testing stated the efficiency of chitosan isolation process from the scales of starry trigger fish. The randement calculation was obtained from the weight of chitosan 
compared to the weight of the powder of starry trigger fish scales as shown in Table 2.

Table 2: Characteristic of chitosan synthesized from the scales of starry trigger fish based on yield by using three different concentrations of $\mathrm{NaOH}$

\begin{tabular}{lccccc}
\hline No & Process & $\begin{array}{c}\text { Concentration } \\
\text { of NaOH(\%) }\end{array}$ & $\begin{array}{c}\text { Initial } \\
\text { Weight } \\
\text { (gram) }\end{array}$ & $\begin{array}{c}\text { Final } \\
\text { Weight } \\
\text { (gram) }\end{array}$ & Yield(\%) \\
\hline 1 & chitosan 1 & 60 & 20 & 3.00 & 15.0 \\
2 & chitosan 2 & 50 & 30 & 16.05 & 53.5 \\
3 & chitosan 3 & 40 & 54 & 16.24 & 30.0 \\
\hline
\end{tabular}

Further characteristic of synthesized chitosan is listed in Table 3.

Table 3: Characterization of water, ash and protein content of chitosan synthesized from starry trigger fish

\begin{tabular}{lcccc}
\hline No & Process & $\begin{array}{c}\text { Water } \\
\text { Content(\%) }\end{array}$ & $\begin{array}{c}\text { Ash } \\
\text { Content(\%) }\end{array}$ & $\begin{array}{c}\text { Protein } \\
\text { Content(\%) }\end{array}$ \\
\hline 1 & chitosan 1 & 6.02 & 88.50 & 2.29 \\
2 & chitosan 2 & 3.43 & 87.67 & 1.07 \\
3 & chitosan 3 & 5.05 & 91.80 & 1.08 \\
\hline
\end{tabular}

The Table 3 shows that the water content and protein content of all chitosan were below $10 \%$, however, ash content for the three chitosan were still very high indicated the high content of mineral in the scales of starry trigger fish. The hardness of the scales of starry trigger fish indicated the high content of mineral component of materials. The higher mineral content the harder mineral component of the material Talumepa, et al., (2016). ${ }^{15}$ As biopreservative, chitosan must have water content below $10 \%$. So this synthesis chitosan is good water content because all chitosan have water content below $10 \%$. With low water content so microorganisme can not life in chitosan.

Characterization of synthesized chitosan was carried out by FTIR to determine the formation of $\mathrm{NH}_{2}$ groups in chitosan and to calculate the deacetylation degree of chitosan. The results of spectrometry from FTIR are shown in Figures 3.

Figure 3 shows the chitosan FTIR spectra from standar chitosan comercil. Comercil chitosan is a chitosan that is sold in general. The bonds in the FT-IR spectra of standar chitosan is $-\mathrm{OH}$ stretching $3858 \mathrm{~cm}^{-1}$, -NH stretching $3609 \mathrm{~cm}^{-1}$, -CH stretching $2862 \mathrm{~cm}^{-1}$, amide 1 band $1643 \mathrm{~cm}^{-1}$, amide 2 band $1552 \mathrm{~cm}^{-1}, \mathrm{CH}_{2}$ bending $1421 \mathrm{~cm}^{-1}$, CO-stretching $1022 \mathrm{~cm}^{-1}, \mathrm{CH}_{3}$ wagging alone chain $752 \mathrm{~cm}^{-1} .{ }^{16}$

Figure 4 shows the chitosan FTIR spectra from the deacetylation process with $60 \% \mathrm{NaOH}$ (chitosan 1), $50 \% \mathrm{NaOH}$ (chitosan 2), and $40 \%$ $\mathrm{NaOH}$ (chitosan 3). Characteritation of comercil chitosan, chitosan 1, 2, 3 shows Table 4.

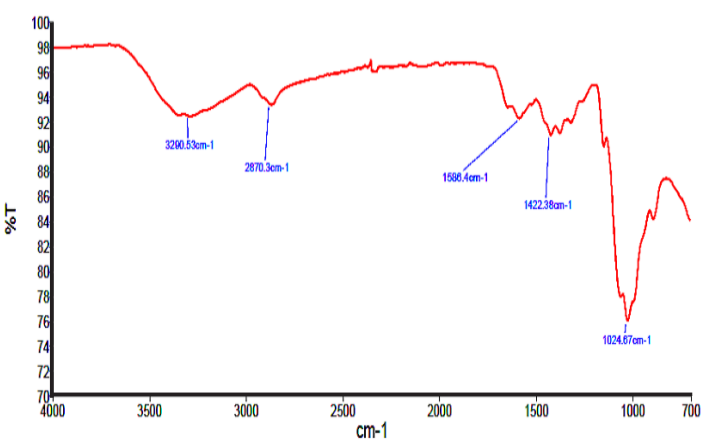

Fig.3. FTIR Spectra of Standar Comercil Chitosan

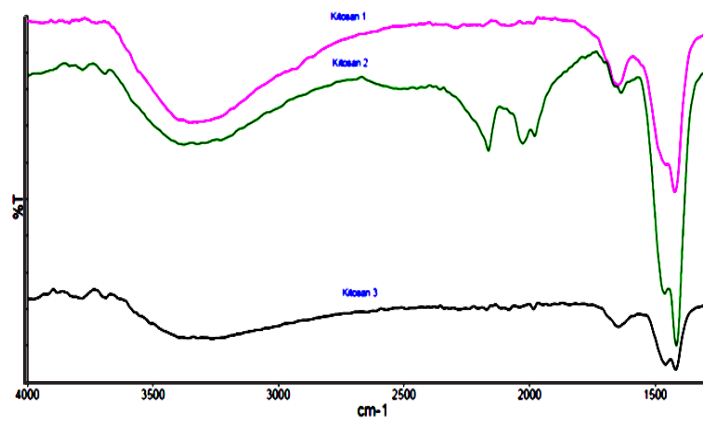

Fig. 4. Chitosan FTIR Spectra with $60 \% \mathrm{NaOH}$ (chitosan 1), $50 \% \mathrm{NaOH}$ (chitosan 2), 40\% $\mathrm{NaOH}$ (chitosan 3

Table 4: Characteritation of chitosan 1, 2, 3

\begin{tabular}{lcccc}
\hline Vibration & \multicolumn{4}{c}{ Wave Number (cm ${ }^{-1}$ ) } \\
& Comercil Chitosan (Fig.3) & Chitosan 1 & Chitosan 2 & Chitosan 2 \\
\hline -O-H & 1422,38 & 1419 & 1412.87 & 1415,7 \\
-N-H streching & 3290,53 & 3353,45 & 3380,35 & 3326,7 \\
-C-O & 1024,67 & 1023 & 1025,75 & 1020,28 \\
-N-H bending & 1586,4 & 1651 & 1635,8 & 1646,1 \\
-C-H group & - & - & 1469 & 1460,8 \\
-C-H alkene group & - & - & 872,70 & 871,05 \\
-C-H strecting & 2870,3 & - & 2163,01 & - \\
\hline
\end{tabular}


Table 4 shows chitosan 1, 2, and 3 have FTIR spectra like comercil chitosan. From the chitosan spectra FTIR, the degree of deacetylation can be calculated based on the ratio of the absorbance of the amida group and the hydroxy group. The calculation of deacetylation degree for this chitosan 1 was $74,25 \%$. The calculation of deacetylation degree for this chitosan 2 wass 47 , $58 \%$. The calculation of deacetylation degree for this chitosan 3 wass 40,19\%. Deacetylation Degrees calculated based on Domzy and Robert formula14 in Saleh, et al., (2015) are listed in Table 5.

\begin{tabular}{|c|c|c|}
\hline No & $\begin{array}{l}\mathrm{NaOH} \text { Concentration in } \\
\text { the Deacetylation Process }\end{array}$ & Deacetylation Degree(\%) \\
\hline 1 & $60 \%$ (Chitosan 1) & 74.00 \\
\hline 2 & 50\% (Chitosan 2) & 47.58 \\
\hline 3 & 40\% (Chitosan 3) & 40.19 \\
\hline
\end{tabular}

The deacetylation degree (DD) value of chitosan 1 was $74 \%$, met the standard minimum quality parameter of chitosan DD which was $70 \%$ (Bastaman, 1989 in Jumadi, 2006) $)^{9}$. The calculation results of DD according Laboratory Protan of chitosan ranges from $70-100 \% .17$ DD of chitosan 2 and 3 not according DD of standar chitosan. This is because the $\mathrm{NaOH}$ concentration was $50 \%$. the
$\mathrm{NaOH}$ with concentration $50 \%$ and $40 \%$ in the deacetylation degree was not able to remove the acetyl group in chitin.

\section{CONCLUSION}

The scales of starry trigger fish as waste product in fish industry is a good material for chitosan synthesis which used $\mathrm{NaOH}$ for deacetylation process. Ash content of chitosan synthesized by this process is still high due to the very hard character of scales of starry trigger fish. The $60 \%$ of $\mathrm{NaOH}$ is the best concentration to obtain chitosan with $74 \%$ DD which met the standard DD of material.

\section{COMPETING INTERESTS}

We declare that we have no competing interests.

\section{ACKNOWLEDGEMENT}

The authors acknowledge the kindness and co-operation of the informal and the local administration officer in Tasik Agung beach, Rembang district, Central Java Province, Indonesia. This research was supported by the Politeknik ATK Yogyakarta, Indonesia.

\section{REFERENCES}

1. Knorr, D. Use of Chitinous Polymers in Food-A Challenge for Food Research and Development. Food Technology., 1984, 38, 85-97.

2. Azis, N.; Gufran, M.F.B.; Pitoyo,W.U.; Suhandi., Hasanuddin Student Journal Vol., 2017, 1(1), 56-61.

3. Hermiyati, I.; Sya'bani, M.W.; Silvianti, F., The 7th International Seminar on Tropical Animal Production., 2017, 473-484.

4. Suhardi. Book of Monograf Chitin dan Chitosan. Pusat Antar Universitas, Food and Nutrition, Universitas Gadjah Mada., Yogyakarta., 1992.

5. Muzarelli, R.A.A. Chitin In GO Aspinall, Polysaccharides., 1985,3, Academic Press. New York.

6. Sugiyo.The Study of the Use of Green Crab (Scylla serrata) as an Adsorbent for Cobalt (III) and Nickel (II) Metal lons in Medium
Water. Tesis. Jurusan Kimia FMIPA UNY, Yogyakarta., 2001.

7. Muzzarelli, RAA. Chitin. Chitin. Pergamon Press. Oxford, UK., 1977.

8. Ahlafi, $\mathrm{H}$; Moussout, $\mathrm{H}$; Boukhlifi, $\mathrm{F}$; Echetna, M; Bennani, M.N; and Slimane, S.M, Mediterranean Journal of Chemistry., 2013. 2(3), 503-513.

9. Bastaman, S. Studies on degradation and extraction of chitin and chitosan from prawn shells (Nephrops norregicus). Thesis. The department of Mechanical Manufacturing, Aeronautical and Chemical Engineering. The Queen's University of Belfast. England., 1989.

10. Trung, T.S; Thein-Han, W.W; Qui, N.t; Ng, C.H; Stevens, W.F., Bioresour Technol., 2006, 97(4), 659-663.

11. Muzzarelli, R.A.A; Rochetti, R. Journal Carbohydr Polym., 1985, 5, 46177. 
12. (AOAC) Association of Official Analytical Chemist., Official Methods of Analysis (18Edn)., The Association of Official Analytical Chemist. Inc. Mayland. USA., 1999.

13. Khan, S.H. ; Bhatti, B.M., Pakistan Vet. J., 2002, 22(1), 27-30.

14. Saleh, A; Mukhtar, S.A; Fawwaz, M; Pratama, M., Journal of Chemical and Pharmaceutical Research., 2015, 7(11), 265-269.
15. Talumepa, A.C.N.; Suptijah, P.; Wullur, S.; Rumengan, I.F.M., Jurnal LPPM Bidang Sains dan Teknologi., 2016, 3, 1.

16. Puvvada, Y.S; Vankayalapati, S; Sukhavasi, S., Int Curr Pharm J., 2012, 1(9), 258-263.

17. Ifa, L; Artiningsih, A; Julniar; Suhaldin., Journal of Chemical Process Enginering., 2018, 03(01), 47-50. 